\title{
Pela voz de Luandino Vieira
}

\author{
Rita Chaves e \\ Jacqueline Kaczorowski*
}

Nas histórias das literaturas há escritores que pela dimensão de sua obra tornam-se figuras fundamentais. Há também outros que, pela força do que viveram, convertem-se, eles próprios, em grandes personagens, impondo-se aos nossos olhos como passageiros de travessias incomuns. Nas Literaturas Africanas de Língua Portuguesa, cujos repertórios foram produzidos em espaços de exceção - o exílio, a clandestinidade, os maquis e/ou a prisão -, deparamo-nos com percursos que nos conduzem para além dos limites dos textos e a eles nos fazem regressar para novas leituras. $\mathrm{O}$ aspecto extraordinário de certas trajetórias explica a importância de ouvir alguns escritores, não para encontrar em suas vozes a melhor explicação de suas obras, mas porque elas nos trazem um conjunto de referências que não estão consolidadas em nosso universo cultural e a História ainda não pôde configurar. Em se tratando de Angola e seu convulsionado processo histórico, não há dúvida acerca da relevância de certos depoimentos.

É claro que 40 anos na vida de um país é muito pouco para avaliações decisivas. E a falta de paciência histórica que tinge o nosso olhar nos leva, tantas vezes, ao equívoco. Mas há certezas inscritas na pedra do tempo. Entre elas destacam-se a importância de um escritor e a sua capacidade de iluminar o itinerário de uma literatura, a do seu pais, do país que ele, de diversos modos, ajudou a forjar. Em 2015 contamos quatro décadas da independência de Angola e, a despeito de tudo, podemos celebrar uma grande virada na história do colonialismo. Mas é válido recordar que dez anos antes um autor e um livro estiveram no centro de um forte golpe à opressão colonial: José Luandino Vieira e Luuanda ultrapassariam os domínios do literário e se colocariam como peças de um contexto político sem volta. Escritas na prisão e dela escapando por caminhos inusitados, as estórias de Luuanda conquistaram um prêmio, o de Novelística da Sociedade Portuguesa de Escritores, e provocaram um notável abalo na atmosfera que envolvia a colônia e a

* Universidade de São Paulo - USP 
metrópole. De tão significativos, o livro e os episódios desencadeados mereceram dois volumes organizados pelo pesquisador Francisco Topa: Luuanda há 50 anos: críticas, prémios, protestos e silenciamentos ${ }^{1}$ e Luandino por (re)conhecer: uma entrevista, histórias dispersas, bibliografia ${ }^{2}$. O material ali reunido atesta a importância do fato histórico, oferecendo dados preciosos para a compreensão do contexto, e aponta para a relevância da obra. A publicação em Portugal de uma edição especial da coletânea, com base numa edição apócrifa e com emendas do autor, reafirma a inesgotável energia de um texto que permanece conquistando e inquietando leitores. Vale a pena, portanto, fazermos desses cinquenta anos também um pretexto para ouvirmos uma vez mais a voz de José Luandino Vieira, o autor desse livro que se tornou um marco decisivo na história externa e interna da Literatura Angolana.

Nas páginas seguintes, Luandino abre-nos alguns roteiros de sua vivência, dá-nos pistas da sua formação literária, partilha angústias e leituras do presente, dividindo, com leveza e profundidade, algumas das perplexidades que o presente angolano acorda. E fala, obviamente, de Luanda, essa cidade em que ele viveu e foi por ele reinventada nas narrativas de uma nacionalidade dolorosamente construída.

1 TOPA, Francisco (Org). Luuanda há $\mathbf{5 0}$ anos: críticas, prémios, protestos e silenciamentos. Porto: Sombra pela Cintura, 2015.

2 TOPA, Francisco J. J. Luandino por (re)conhecer: uma entrevista, estórias dispersas, bibliografia. Porto: Sombra pela cintura, 2014. V. 1. 
RC-JK: O que conduziu o escritor ao seu ofício? Teria sido mesmo a experiência da infância que em sua obra tem uma dimensão tão marcante? LV: O que me conduziu à Literatura... Como autor? Agora eu sou capaz de me lembrar dessa parte muito antiga da minha infância, quando eu aprendi a ler. Naquele tempo, aprendia-se a ler exatamente no momento em que se entrava para a escola, por volta dos 7 anos de idade. Até os 7 anos de idade, a gente era feliz, brincava... Penso que o que me conduziu à Literatura foi o facto de ter sido um leitor muito persistente e apaixonado. Não havia muitos livros lá em casa, mas aqueles que havia eu li; li e reli. Depois, na escola, também lia. Eu lembro-me que ganhei o hábito de ler tudo quanto estava escrito e que às vezes a minha mãe se irritava; ela ficava envergonhada por eu ler em voz alta a publicidade interior no machimbombo. Portanto, o interesse pela Literatura veio da leitura. Depois, no Liceu, veio do facto de haver um jornal, que era $\mathbf{O}$ Estudante.

RC-JK: E chegou a colaborar nesse jornal?

LV: Depois que saí do Liceu, com os meus 14 ou 15 anos. Eu penso que publiquei aí um conto, produto de pequenos textos que eu escrevia por influência do Antônio Jacinto. Antônio
Jacinto, que era mais velho que nós aí uns 10, 11 anos, nos obrigava todos os anos a fazer uma espécie de jogos florais e classificava essas nossas redações, que nós chamávamos pomposamente "contos", com prêmios. E eu lembro que uma vez eu escrevi um desses contos que se situava na cidade do Porto, onde eu nunca tinha estado, e que falava também de uma figura que eu também nunca tinha visto - um mendigo. Em Luanda naquele tempo não havia mendigos, não havia gente a pedir esmolas. Então por que um mendigo? Devo ter sido influenciado pelos contos de Eça de Queirós, que foram os contos que mais me agradaram quando eu andava no Liceu, portanto por volta dos meus 15, 16 anos; Eça de Queirós e Fialho de Almeida. Então ele chamoume a atenção e disse "Bom, não ganhas; não te dou o prêmio porque tu vives aqui, há tanta coisa à tua volta, e estás a escrever sobre coisas que tu não sabes, não vistes, em terras onde nunca foste, quando basta olhar à volta. Portanto, no próximo ano, tu vais continuar a escrever e toma lá este livro para ler". E deu-me As vinhas da ira, de Steinbeck. Pronto, então eu passei a ler cada vez mais e cada vez melhor, porque Jacinto me ia abrindo outros horizontes. E com António Cardoso e Antônio Carpinteiro, que era meu primo, fazíamos um pequeno jornal manuscrito no bairro. 
RC-JK: Qual era o bairro?

LV: O bairro era o Braga, onde hoje é a Sagrada Família, em Luanda. Fazíamos aquilo em papel de 50 linhas e exemplar único e eu, como tinha boa caligrafia, é que escrevia os artigos. E como tinha jeito para o desenho, também fazia os desenhos. Foram esses desenhos que eu comecei primeiro por assinar com o nome de Luandino. Porque nós usávamos muitos pseudônimos, como para dizer que tínhamos muitos colaboradores. Além disso, quando eu tinha 14, 15 anos, fazíamos também um jornalzito de banda desenhada, no Liceu Salvador Correia de Sá, que se chamava O Gaiato. Tudo isso me deu interesse pelas letras, pela Literatura. Eu lia muito. Jacinto emprestava-me tudo; desde Górki, Ponson du Terrail, depois Max du Veuzit, depois Turgueniev, era assim uma misturada; tudo o que eu queria era que houvesse letra impressa.

RC-JK: E a escola favorecia esse interesse?

LV: Como era para produzir o uso obrigatório da Língua Portuguesa, sobretudo para a gente, era muito centrado na Literatura, nos autores. E calharam alguns bons professores de Português, que era o nome da disciplina naquele tempo.
RC-JK: A biblioteca era, portanto, um lugar procurado por você?

LV: No Liceu, não frequentava muito a biblioteca porque havia muitas coisas a fazer: futebol, basquetebol, voleibol, as miúdas, passear pela cidade, às vezes no autocarro a acompanhar A, acompanhar B, no machimbombo, ia para os Coqueiros, depois ia acompanhar outro colega que ia para São Paulo. E tínhamos também, à noite, o hábito de no fim do jantar nos reunirmos para tomar um café e depois saíamos a andar pelas ruas de Luanda em travessias, que iam desde o Bairro do Café, na volta por São Paulo, descendo a marginal, subindo pra Fortaleza vindo pra Cidade Alta e voltando à casa, por volta da meia-noite, uma da manhã. Aí, nessas viagens, com o António Cardoso e o Helder Neto e outros, nós discutíamos tudo. Queríamos virar o mundo do avesso, fazer outro mundo. As conversas de política eram sempre nesses passeios, porque, sentados num café, havia sempre toda espécie de informadores. E muita literatura!

RC-JK: Quais são as suas lembranças dessa iniciação literária?

LV: Se bem me lembro, o primeiro conto que eu escrevi era uma história passada na Idade Média. Eu mesmo fiz um livrinho... Eu devia ter uns 14 anos, não sei onde isso foi parar. Mas depois 
lembro-me dum conto, "O Cartaz", que foi publicado no $\mathbf{O}$ Estudante, o jornal do Liceu. Pronto! E depois fui escrevendo já as coisas que vinham da minha memória. Eu ainda não tinha 20 anos, penso eu, e já escrevia coisas a partir da memória de um tempo a que eu tinha assistido e que estava em vias de extinção. Um tempo que está em alguns contos e que mais tarde veio a dar o Nosso musseque, que também foi tirado da experiência desta época. Com esta resposta toda, atrapalhei tudo, mas está aí; foi por ter começado a ler, foi por ter lido muito. Na biblioteca do Liceu Nacional Salvador Correia de Sá eu li o Fernão Lopes, e depois um pouco de Fernão Mendes Pinto, e depois li todos aqueles livros que eram obrigatórios; Júlio Diniz, o Luís de Camões...

RC-JK: E a literatura que não era obrigatória, como chegava a você?

LV: O Jacinto é que nos dava. Ele é que me deu a parte da literatura internacional e também algumas coisas que eles já iam fazendo lá - coisas do grupo dos "Novos Intelectuais de Angola". Era assim que se chamavam: o "Movimento dos Novos Intelectuais de Angola". Eu lembro-me de ter visto uma folha de papel timbrado, "fulano de tal" (não digo o nome), e embaixo: "Poeta do Movimento". E era assim que eles escreviam as cartas uns para os outros, porque estavam todos espalhados: no Namibe, em Malanje, não sei se alguém no Uíge, e em Luanda...

RC-JK: Em síntese, o leitor foi o pai do escritor. Mas como nasce o escritor? $\mathbf{L V}$ : Mais tarde, o que me movia para isso, penso que foi assim uma espécie de vaidade, uma coisa assim. O que eu queria também era ver o meu nome na capa de um livro. Isto porque lembro que, quando peguei esse conto e fiz eu mesmo um livro, dobrei e colei e pus meu nome na capa, o que eu estava a querer era ser escritor, no sentido de ter um livro publicado com o meu nome na capa. Lá o conteúdo, a qualidade literária... não me lembro de estar preocupado com isso; agora, o que se revela, é que eu queria ser escritor. Era uma espécie de notoriedade, talvez. Não sei porque eu buscava isso; eu jogava basquete, eu jogava futebol; era uma criança, um jovem perfeitamente adaptado, normal, que fazia o que toda gente fazia... ainda hoje procuro saber porque é que eu queria pôr o meu nome na capa dos livros!

RC-JK: Nessa altura você ainda não tinha lido nem o Assis Junior, nem o Castro Soromenho, cujos sinais sentimos em seus textos?

LV: Não, o que eu tinha lido naquela altura era Oiro Africano, de Julião Quintinha; eu tinha lido 4 ou 5 
romances da chamada Literatura Colonial que meu pai tinha. Além da Bíblia, que eu lia, e desses romances, eu não me lembro de outros livros. Lembro-me perfeitamente desse Oiro Africano. E depois li, mais tarde, uns contos do Henrique Galvão; mas nem Assis Junior, nem Soromenho. Só mais tarde, isso foi já depois de estar no serviço militar, portanto 21 anos, então sim: Soromenho, o Assis Junior, mas, sobretudo, Óscar Ribas, o Uanga do Ribas. A entrada nessa parte da Literatura Angolana foi mais tarde, portanto, quando a Mensagem já tinha desaparecido e quando o "Movimento dos Novos Intelectuais de Angola" também já estava totalmente disperso, porque Agostinho Neto tinha vindo estudar, Humberto da Sylvan não sei onde parava e os outros também não. Só o Jacinto é que mantinha um pouco viva essa chama entre nós, já por volta de 58, 59 .

RC-JK: Os romances em outras línguas eram lidos no original?

$\mathbf{L V}$ : Eu sabia inglês (eu trabalhava numa empresa com a companhia marítima e exatamente arranjei esse emprego porque sabia inglês. Tinha aprendido inglês vendo os filmes; eu via muito cinema, então eu via os filmes abaixado, de tal maneira que não pudesse ler as legendas, para ouvir a língua inglesa.
E foi assim que eu aprendi a falar mal o inglês, com sotaque do Texas, pois só via filmes de cowboys) e Jacinto dava-me, às vezes para traduzir. “Traduz este poema e leia este livro". E lembro-me que me deu alguns livros da Renascença Negra do Harlem, Claude McKay, Langston Hughes, todos aqueles. Era um pequeno volume, não sei se era da Modern Library, de Nova Iorque, já não me recordo. Sei que foi outro componente na minha formação literária.

RC-JK: Com a atividade literária começam também os problemas com a repressão?

LV: Eu fui escrevendo aqueles contos de A Cidade e a Infância. Depois, por volta de 1957, eu tinha aqueles contozinhos que Jacinto já tinha lido. Eu ainda estava no serviço militar, em 58 trabalhava no quartel general e resolvi editar um caderninho com 4 histórias daquelas que posteriormente apareceram na A Cidade e a Infância. O caderno foi feito e já estava pronto, eu paguei, só faltava pegar... Eu paguei em quatro prestações; passava lá todos os dias para ver as provas e em um fim de tarde, eu saí do quartel general, que era lá em cima, na Cidade Alta, subi a calçada do Liceu - a tipografia era mesmo na calçada em frente ao Liceu, naquele largo; tipografia Globo, 
penso que se chamava assim... Fui lá e disseram “Ah, amanhã está tudo pronto, só falta coser a arame, mas se quiser leve já dois ou três”. E eu levei, penso que trouxe 4, e nessa noite dei um a António Cardoso e guardei um, eram três, e meti um no correio para Antônio Simões Junior, que era um português que estava exilado em Avellaneda, perto de Buenos Aires, com quem eu tinha correspondência não muito regular, mas umas cartitas. Enviava-lhe um livro ou outro e ele nos enviava sempre tudo. Eu ainda hoje tenho esses livros; o Guillén, aquela coleção da editorial Losada... Então lembro-me que fiz uma dedicatória, mandei pelo correio, penso que recebeu e que guardou. No dia seguinte de manhã, quando passei pela tipografia, disseram-me que tinham estado as autoridades e que tinham apreendido a edição toda. O próprio administrador do Conselho de Luanda tinha ido lá, com não sei o quê, fez um auto e levou tudo. Eu reclamei, pedi audiência já não me lembro a quem lá no governo e disseram-me "Não, não; não é por nada, é porque o senhor está no serviço militar e publicou um livro sem autorização do general comandante".

RC-JK: E como foi o percurso até a edição da Casa dos Estudantes do Império?
LV: Eu guardei o título, tinha feito o desenho da capa também e depois, quando a Casa dos Estudantes do Império começou com a Coleção dos Autores Ultramarinos, eu tinha ido à Lisboa, depois da primeira prisão, se não me engano, em 59. Fui ainda para ver se participava de um congresso de cineclubes que o Salazar não autorizou. Não houve congresso, mas eu já tinha viajado, aproveitei para conhecer as minhas avós e deixei os contos, de maneira que não sei se foi o primeiro, o número 1 , ou se foi o número 2 , da Coleção de Autores Ultramarinos da Casa dos Estudantes do Império A Cidade e Infância; um livrinho pequenino, com umas letras azuis e uns desenhos, aí já reproduzidos por João Moraes, que era um amigo com quem eu partilhava um apartamento mesmo no bairro do Braga, musseque Braga, como se chamava no tempo, onde agora é a Sagrada Família, aquela zona que também depois pomposamente se chamou Alvalade, que eram as barrocas onde nós brincávamos. Foi assim que comecei a escrever e a publicar. Tentei fazer uma edição do autor, deu o resultado que deu... e depois com o mesmo título, mas com outros contos, o livro saiu na Coleção "Autores Ultramarinos" e pronto. 
RC-JK: Como você vê esse livro hoje? LV: A Cidade e a Infância, pronto, é um livro que... as versões que estão publicadas aparecem já com data, mas eu escrevi aquilo quando tinha uns 17 , 18 anos, e às vezes fico a olhar para o livro e digo: "Não devia ter publicado obviamente aquilo". Mas eu penso que... fui eu que escrevi, escrevi naquela altura, era aquilo e devo manter o livro publicado. Porque às vezes chega uma tentação de tirar tudo e ficar só um livro.

RC-JK: Naquela altura, você já tinha lido os escritores brasileiros também?

LV: Ah, naquela altura, o António Jacinto dava-nos o Cruzeiro e a Manchete, nós líamos; líamos aquelas crônicas, não sei se era no Cruzeiro ou se era na Manchete, na última página, que era da Rachel de Queiroz. E eu e o Jacinto, que se correspondia não sei com quem no Brasil, mais tarde recebemos muitos livros pela mão de um marinheiro do Custódio de Melo, que fazia a volta para dar instrução aos cadetes da marinha brasileira, e que parava em Benguela e Luanda. Nessa paragem Jacinto recebeu muita coisa, recebeu inclusive os Estatutos do Partido Comunista Brasileiro, uma série de literatura marxista, manual do materialismo dialético, sei lá, e romances da... Editorial Vitória, pode ser?
RC-JK: Sim, era uma editora ligada ao Partido Comunista.

LV: Bom, e esses livros o Jacinto davanos para lermos. Começamos com os romancistas do Nordeste: Jorge Amado, obviamente, depois José Lins do Rego, Rachel de Queiroz e Graciliano. Graciliano, As Memórias do Cárcere - tudo estava sempre relacionado em primeiro lugar à questão política; e foi assim que fui ficando também com a leitura da literatura portuguesa, porque de Coimbra e Lisboa recebíamos dos escritores neo-realistas: "Sob o signo do galo", aquelas coleções de poesias, os livros traduzidos da Editorial Gleba... alguns desses livros eu ainda tenho, mas como eu não guardo muitos livros, dou quando gosto, distribuo para outros lerem, já não sou capaz de dizer exatamente... Alves Redol, Carlos de Oliveira, Fernando Namora regularmente líamos; e do Brasil, eram sobretudo esses do Nordeste. Lembro que, por vezes, eu tinha discussões com o Cardoso por causa do Jorge Amado e Érico Veríssimo. E quando Jacinto entrava na discussão, era Jorge Amado, Érico Veríssimo e Graciliano, porque Jacinto era um gracilianista... para ele, o velho Graça é que era!... e pronto, foi assim que fiz a minha aprendizagem literária. 
RC-JK: Em 59 você já tinha sido preso. Qual era a acusação?

LV: Eu fui preso em julho. A acusação era a mesma; eu fui preso no âmbito do Processo dos 50; foi presa toda a gente, do MIA, do MINA, do MNL... enfim, aqueles grupos. Todos tinham a mesma intenção, todos tinham o mesmo objetivo, e cada um, de dois, três, quatro, cinco pessoas do seu lado faziam um grupo, faziam panfletos, distribuíam panfletos, era uma agitação muito grande. Eu fui preso quando a PIDE desencadeou a primeira grande ação e começou a prender toda a gente desses grupos. Prendeu também um grupo que estava ligado à Sociedade Cultural de Angola, Maria Julieta Gandra... Uns eram portugueses progressistas que estavam ou desterrados em Luanda, ou tinham vindo trabalhar porque não conseguiam trabalhar em Portugal, e alguns indivíduos brancos angolanos que se juntavam ali à volta da Sociedade Cultural de Angola. Eles foram presos, atrás de uns foram outros e, chegou a minha vez também.

RC-JK: E foram todos condenados?

$\mathbf{L V}$ : Eu fui preso, o processo foi para o tribunal, mas o juiz não se pronunciou, quer dizer, não encontrou material de culpa. Eu fui um dos últimos e quando fui preso já o engenheiro Calazans Duarte tinha avisado "Só sabem isto, assim, assim; mantém essa versão". E a minha versão era de que eu não sabia o que eram aqueles panfletos, na verdade me tinham dado por debaixo das portas, nas caixas de correio e em tudo quanto era lugar. Como coincidiu com as eleições portuguesas, "eu pensava que eram panfletos de Humberto Delgado", porque todas essas pessoas visivelmente participavam da campanha para a eleição do General Delgado. "Não, mas o que é que pensas da independência? Não senhor, são panfletos estes a pedir a independência", "Sei lá, nunca ouvi falar disso". Fiz-me de ingênuo e, quando fomos ao juiz para confirmar os autos da PIDE, mantive a versão e o juiz despronunciou. $\mathrm{O}$ juiz pronunciou só aqueles cerca de 50, mas eram muito mais...

RC-JK: Você tinha saído da tropa fazia pouco tempo?

LV: Não, eu tinha saído da tropa em 56, 57. Então o que é que sucedeu depois? Eu saí e disse "pronto, vou viajar". Com aquela prisão, tinha perdido aquele emprego; trabalhava na Volvo. "Vou à Portugal”, e como estava programado um congresso dos cineclubes, e eu pertencia ao cineclube de Luanda, fui. Claro, estive em Portugal, contactei com a gente da Casa dos Estudantes do Império, fiquei a conhecer melhor aquilo, voltei, arranjei um emprego 
numa empresa que se tinha instalado para ajudar a construir a barragem de Cambambe. E casei em 1960, e depois em 61 fui preso, quando já tinha tudo preparado para sair para o estrangeiro. Porque já tinha começado a luta armada em 61. Eu ia para Londres e de Londres ia para o Gana; e, no Gana, eu ia ter com o MPLA.

RC-JK: E os livros seguintes, onde foram escritos?

LV: A vida verdadeira... foi terminada de escrever em Lisboa, em 61. Penso que acabei em novembro ou dezembro de 61; terminei, uns dias antes de ser preso, A vida verdadeira de Domingos Xavier, e deixei o manuscrito. E depois, na cadeia, escrevi as Vidas Novas. E depois, penso que ainda na cadeia de São Paulo, escrevi a "Vavó Xíxi e seu neto Zeca Santos", mas levei para a primeira esquadra, na Baixa, onde é agora o comando da polícia - aquele prédio azul muito antigo, está mesmo na marginal - e aí escrevi a "Estória da galinha e do ovo". Estávamos em uma daquelas cadeias que às sextas, sábados e domingos se enchiam e ficavam 80 pessoas num lugar de 12, uma coisa assim. Eram as grandes rusgas que faziam para depois, na segunda-feira, presumivelmente, irem ao juiz e o juiz atribuía uma sentença administrativa "vai trabalhar para a pesca" ou "vai para o sul" ou "vai para São Tomé" ou "vai para a rua". E uma vez eu vi entrar aquele grupo; um aleijado com um pato, sim. Como nós éramos os três políticos, estávamos numa outra cela aparte. Uma cela terrível, em que um de nós tinha que ficar sempre de noite de guarda porque saíam aquelas ratazanas da marginal e vinham...

RC-JK: Com quem você dividia a cela?

LV: Com o Jacinto e o António Cardoso. Fazíamos turnos para vigiar por causa dos ratos, pois os ratos roíamnos os dedos. E essa cadeia era mesmo uma "boa cadeia". Era isso, durante o dia a porta de grades dava para uma oficina de pintura dos automóveis da própria polícia; estavam a pintar com aquelas máscaras e nós dentro da sala. Ainda esta coisa... esta dificuldade que eu tenho ainda com a minha garganta vem daí. Tivemos lá o que... seis meses, sete meses ... em 1963. E então quando vi aqueles desgraçados, inventei a história... "o que é que leva este tipo a roubar patos"? E saiu a "Estória do ladrão e do papagaio"; eu já tinha escrito a "Estória da galinha e do ovo" porque me lembrava daquelas pequenas discussões entre a minha mãe e as vizinhas e as vizinhas entre si por causa das galinhas e dos ovos; aquela confusão. E a "Estória da galinha e do 
ovo" foi escrita mesmo com o sentido deliberadamente político.

RC-JK: Diferentemente das outras estórias?

LV: Enquanto o "o ladrão de patos" era quase um divertimento, a "Estória da galinha e do ovo" não, foi escrita mesmo a partir dum episódio que eu vi várias vezes, não com aquela sequência quase cênica, entra personagem sai personagem, mas eu vi muitas vezes aquela discussão à volta da galinha, a quem pertence um ovo de uma galinha que é alimentada: ao dono da galinha? Então eu disse, pois é, isto é como nós, a nossa terra. Pronto, e o fim que eu encontrei foi realmente pôr as crianças a resolver o problema, porque o problema até ali estava insolúvel. Há duas coisas que precipitam o desfecho que é, por um lado o aumento da repressão - quando os polícias já não querem só o ovo, querem a galinha toda - por outro lado, a resposta das crianças, o futuro, respondendo de uma maneira engenhosa: "bom, como é que a gente vai tirar a galinha?”. E recorrem ao que é tradicional, aquelas cantigas de imitar o canto das aves; uma espécie de parábola, uma coisa assim.

RC-JK: Foi nessa prisão que você leu o Guimarães Rosa?

$\mathbf{L V}$ : Pronto, eu tinha escrito essas três estórias... tinha as escrito e eu recebia visitas. E uma vez o doutor Eugênio Ferreira foi nos visitar, como advogado e tal... e depois, na visita seguinte, falávamos do que estávamos a ler, eu andava a ler José Lins do Rego, penso que o Menino de Engenho... Nós já tínhamos sido, como eles diziam, investigados, "não faz mal nenhum, leiam lá o que vocês quiserem". Claro que não iam livros marxistas. E a minha mulher chegou para visita e trouxe um livro e disse, "olhe, o Eugênio disse que vocês andam aí a ler o José Lins e o Jorge Amado e não sei quê, e o Eugênio manda-te este livro". E era um livro assim grande, Livraria José Olympio, capa amarela, e tinha um título que eu olhei para aquilo e disse "que raio de coisa é essa, 'Sagarana'?", e pus de lado.

RC-JK: Essa leitura provocou grandes mudanças na sua concepção literária?

LV: Os contos estavam escritos, mas eu, nos diálogos, em tudo quanto era diálogo, ou reflexões, portanto diálogos indiretos, eu já tinha utilizado a linguagem popular. Se não, não era possível escrever aquilo, "Kam'tuta" e "sô Zuzé". Mas eu andava a debater comigo próprio, lia aquilo e soava-me falso, porque, muito embora escrevesse com a prosódia que era da minha fala, portanto luandense, havia uma 
diferença entre aquilo que eu escrevia e depois o que diziam os personagens. E era assunto que eu sempre discutia com o Jacinto; ainda nos anos 70 , no Campo de Concentração do Tarrafal sempre discutíamos isso. Porque, muito embora Jacinto tenha escrito o "Vovô Bartolomeu" e eu lembro-me que o que me fazia pensar muito nisso era um conto cujo título era "Aiué", de Cochat Osório. E esse conto, "Vovô Bartolomeu", do Jacinto, que eu tinha lido datilografado, por ele, o original assinado "AJAM", Antônio Jacinto do Amaral Martins. E andava eu a discutir aquilo quando, faço não faço, bom, parei e guardei. Guardei e disse "pronto, agora vou ler" e peguei e disse “pá, vamos lá ler esta coisa, 'Sagarana', que raio de palavra é essa; o que é que isto quer dizer?". E comecei a ler "O Burrinho Pedrês", que é o primeiro. Eu li uma página, duas páginas... E pá, disse "ah pronto, já percebi!". E voltei e, não sei, não mexi em nada; a única coisa que eu fiz nos contos foi forçar um pouco mais, no sentido literário, a linguagem popular que eu já tinha registrado, por ter vivido, por ter ouvido, por continuar a ouvir, por ser dos personagens - inclusive dos ladrões que estiveram ali na cadeia.

RC-JK: A linguagem utilizada por você resultou da combinação entre a leitura e a sua experiência com tantas personagens com quem conviveu?

LV: Inclusive na prisão. Eu falei com eles por um tempo, "o que é que vocês roubaram?, não sei quê..." e cada um contava uma história mais mirabolante... e eu percebi que era legítimo tentar fazer uma linguagem literária a partir daqueles mesmos pressupostos com que, nas camadas populares, se usava a língua portuguesa, que eram (e isso eu já tinha percebido a ler os Missosso do Óscar Ribas. Aí já tinha lido O Segredo da Morta, já tinha lido isso tudo) aquelas alterações na língua portuguesa sobretudo devidas ao facto de preencherem, com vocábulos da língua portuguesa ou da linguagem corrente, estruturas que eram de outra língua na cabeça dos falantes e, portanto, davam aqueles resultados: num caso cômico, em outro caso, quase a dizerem o contrário daquilo que parece que estão a dizer... E disse "pronto"; então foi por aí que comecei a construir essa linguagem literária, que depois fui utilizando ao longo dos livros todos e que nunca mudei... nunca desisti dessa linha, porque fui estudando cada vez mais a língua portuguesa. Eu li tudo quanto era clássico: li os frades todos. Eu gosto muito do Padre Antônio Vieira. Fui estudando, aprendi outras línguas, e, sobretudo, percebi que tinha que regressar a uma língua da minha 
infância, a minha segunda língua, o kimbundu. E fui aprofundando os conhecimentos do kimbundu, chegando ao kimbundu literário. E com os meus colegas, naqueles largos anos do Campo de Concentração, o Mendes Carvalho e os mais velhos, percebi que era, continuo a pensar assim, uma linha correta do desenvolvimento de uma linguagem literária angolana e que o que eu tinha que fazer era assumir isso e fazer isso com o máximo de conhecimento que eu pudesse obter e assumindo o máximo da responsabilidade pelo que está feito, que eu assumo totalmente. Depois, deu uma certa tranquilidade ver escritores que faziam isso sem ser pela via erudita, como o Uanhenga Xitu (o Uanhenga Xitu é aquilo mesmo); e ainda outros escritores que, sendo de língua materna kimbundu, seguiram a mesma via, o Jofre Rocha, o Boaventura Cardoso e outros. E disse: pronto, não é um equívoco meu; pode ser um equívoco total de uma geração, de um grupo, de um momento histórico, pode ser, não sei, mas sinto-me pacificado quanto a isso.

RC-JK: Essa convicção se mantém?

LV: Depois, da experiência de 1975 até 1992 e sobretudo quando, depois de 92 até 96, 97, com o agonizar da Guerra Civil, e com tudo quanto se foi publicando naquela geração dos anos
80 e tal, que se chamam a si próprios de "Geração das incertezas" - mas eram todos muitos certinhos, os das incertezas - fiquei a pensar que a base era essa, esse era o material, e que isso era uma tendência, sei lá, era uma linha de desenvolvimento da literatura nacional angolana. E o que me cabia era ficar tranquilo quanto a isso $\mathrm{e}$ preocupar-me apenas com o aspecto já estético, literário desta questão; não estar mais preocupado com questões linguísticas, ou histórico-linguísticas ou histórico-sociológicas. E quando cheguei a essa conclusão comecei a escrever o que eu queria escrever, que era $\mathrm{O}$ livro dos rios... que é, da maneira como deliberadamente comecei, a mesma coisa, mas escrita de outro modo, sem já me preocupar com nada, nem com ninguém, nem se está certo, se está errado. Portanto, a linguagem literária já noutro nível.

RC-JK: Vamos voltar ao Luuanda, esse livro que marca o itinerário da literatura em Angola. Você não escreve na ordem que aparece no livro. Quem deu a ordem foi você? Depois?

LV: Fui eu quem deu a ordem, porque o livro não se chamava, não era para se chamar Luuanda. O livro era umas sete histórias, depois outras foram reescritas, como a "Estória da menina Santa", depois "Muadié Gil, o 
Sobral e o barril", que está no Velhas estórias, mais uns contos que estão em A Cidade e a Infância, como "Bebiana"... Uns contozinhos... Era para juntar isso tudo em um caderno que se chamava Vadiagem. Naquele tempo pensávamos em termos de cadernos. Era um caderno.

Depois fiz aquela divisão porque, depois de Domingos Xavier, percebi que não valia a pena juntar mais nada. Domingos Xavier já é a entrada dessa linguagem. Vidas Novas também foi escrito deliberadamente, aquelas histórias todas, para mostrar qualquer coisa de novo que estava a passar. Com Luuanda, o material já era muito mais encorpado, mais grosso, mais social, sociológico, histórico etc.

RC-JK: O título e a capa foram escolhidos por você?

LV: O título Luuanda, sim, eu escolhi aquele título e fiz o desenho. O desenho era de uma cubata a escorrer, como se fosse uma pixagem numa parede, fui eu que fiz, e o título Luuanda também escolhi eu.

RC-JK: O livro foi escrito na prisão. E como os originais saíram de lá?

LV: E saíram essas estórias, saíram nas... não sei muito bem como é que saíram, sei que as fichas saíram, na suas versões originais, nas fraldas do Xexe.
Porque o Xexe tinha 3 ou 4 meses; ia visitar-me e, uma das maneiras para afastar o guarda, que estava ali ao lado nas visitas, era trocar a fralda da criança. O guarda afastava-se, porque não queria ver o que estava a ver, e então eu levava já 4 ou 5 folhas dobradas já do tamanho de bolacha, aquelas bolachas. Uma vez foi assim que eu as fiz sair... eles faziam a vistoria de tudo o que vinha de casa e abriam, então o pacote de bolachas já vinha fechado no celofane, tudo, e não mexiam. De maneira que eu disse "Bom, eu vou pôr isto lá dentro e vou buscar a roupa suja", que era para depois eles verem a roupa; se saía também qualquer coisa da cadeia para a família. A Linda foi tirando umas folhas, de uma maneira ou de outra, e tinha o original com ela. Quando fomos lá para baixo, para a $4^{\mathrm{a}}$ esquadra, na Baixa, onde escrevi a "Estória do ladrão e do papagaio" e completei, portanto, as três estórias, fiz o trabalho todo e depois entreguei na visita lá embaixo; já não estávamos sob a alçada da PIDE e as versões já trabalhadas...

RC-JK: E a publicação?

LV: Ela mostrou a uns amigos que trabalhavam ou escreviam para o jornal $\mathrm{ABC}$, e decidiram: "ah, vamos publicar". Então fizeram a edição do Luuanda, aquela pequenina edição, que saiu e foi-me atribuído o Prêmio Maria 
José Mota Veiga, que a Linda foi receber das mãos do governador da Província de Luanda.

RC-JK: E como o livro desembarcou em Portugal?

LV: Então, depois disso, a Rute Magalhães tinha ido a Luanda, ou mandaram os livros para a Rute, em Portugal, e ela entregou na Casa dos Estudantes do Império, em Lisboa, e depois também em Coimbra. E fizeram a distribuição pelo Urbano, o Alexandre Pinheiro Torres e outros... o João Gaspar Simões, o Abelaira... e eles fizeram suas críticas nos jornais e as críticas da época, e o livro foi distinguido pela Sociedade Portuguesa de Escritores com o prêmio. E deu aquele rebuliço todo, mas eu estava no Campo de Concentração; isso já foi em 64,65 .

RC-JK: Mas a complicada trajetória do livro não termina aí. Há ainda o episódio daquela falsa edição.

LV: Essa é mais uma história. A capa referia uma gráfica de Belo Horizonte, como se a edição viesse de lá. Mas a verdade é que essa edição foi feita à minha revelia. Com o escândalo à volta do Prêmio, que envolveu a destruição da Sociedade Portuguesa de Escritores, o livro tornou-se muito procurado. E dois agentes da PIDE fizeram o livro, na tipografia Pax, em Braga, distribuíram e ganharam bastante dinheiro com aquilo. O meu advogado resolveu meter um processo em tribunal e isso gerou uma outra história. Até pelo tipo de papel era fácil identificar a tipografia, mas perdi o processo, porque não se conseguiu provar nada - embora tudo fosse evidente. E ainda fiquei com as custas do processo.

RC-JK: Você escrevia tudo a mão?

LV: Eu escrevia tudo a mão; aqueles contos, quem datilografou não fui eu; deve ter sido a Linda, porque eu mandei tudo escrito a mão. Naquele tempo eu não tinha máquina de escrever, só depois, mais tarde, deixaram entrar a minha pequena Hermes Baby, que me acompanhou. Quando eu cheguei ao Campo ainda ficou apreendida, depois deram-me de novo, mas eu continuei a escrever a mão. Tudo quanto eu escrevia para o Luuanda era escrito a mão. Depois, os originais de No antigamente, na vida, eu próprio passei à máquina, naquela máquina; e... não sei, dei. $\mathrm{E}$ noutro dia tive a surpresa de encontrar "Lá, em Tetembuatubia", o original datilografado, com o meu compadre Arnaldo Santos; "Como é que isso veio aqui parar?”, não sei, coisas que eu dava. Quando não tinha mais nada que mandar aos amigos, fazia um postal, ou dava alguma coisa. 
RC-JK: E os originais de Luanda, a senhora a catar os caixotes de lixo. onde estão? Era para retomar aquele dado sóciohistórico da burguesia do fim do século

LV: O original de Luuanda existia, e eu ofereci. Depois do 25 de abril, o Arménio Ferreira - Doutor Arménio Ferreira, que era o coordenador do Comitê 4 de Fevereiro do MPLA em Lisboa, que era o meu coordenador naquela altura, quando saíram os presos políticos das cadeias, fizeram-se vários leilões e venda de quadros e livros, e eu dei o original de Luuanda, que foi vendido, não sei como, não sei a quem, nem sei aonde; sei que foi vendido para angariar fundos para as famílias dos presos políticos que saíram depois do 25 de abril.

RC-JK: Quando lemos o livro, percebemos uma unidade naquela organização. Temos o "Vavó Xíxi...”, que é uma evocação, depois temos a "Estória do ladrão...", que é o presente, e temos a "Estória da galinha e do ovo". Isso foi pensado por você quando organizou?

LV: Não, não. Achei que sim, que devia fechar com a "Estória da galinha e do ovo", porque é a que fica aberta, as outras ficam fechadas... Na primeira, sim, um dos motivos do "Vavó Xíxi" era a própria personagem. Eu vi aquela personagem na marginal. Eu morava na rua Mota Feo, eu via todos os dias
XIX, que foi destruída e cujos restos eu conheci no bairro dos Coqueiros, na Ingombota e que foram cada vez mais afastadas da parte dita urbana da cidade, mas que nós encontrávamos em todo lado. E isso eu via nos Coqueiros.

RC-JK: Esse era um bairro especial?

LV: O bairro dos Coqueiros ficou preservado ali, encravado, e como eu jogava no Atlético - o Atlético era ali no bairro dos Coqueiros -, nós tínhamos aquela vivência no Atlético. Era como se vivêssemos num bairro dos anos do fim do século, nos anos 50, 1950. Era assim um gueto; não era um gueto porque tudo aquilo se misturava muito com a cidade Baixa, mas era um tempo fora daquele tempo. Já à volta havia aqueles prédios, havia aquilo tudo e o Clube Atlético, naquele bairro dos Coqueiros, persistia, subsistia. Portanto as histórias não foram deliberadamente arrumadas... se calhar, foi mesmo o próprio tema que as obrigou a ficar assim. Às vezes perguntam-me qual é a que eu gosto mais; eu continuo a dizer que a que eu gosto mais é a de Vavó Xíxi e de seu neto, por ser a história da fome. 
RC-JK: Numa entrevista à Margarida Calafate Ribeiro, em 2005, você define Luuanda como um contra-mapa da cidade.

LV: Um contra-mapa em que sentido?

RC-JK: A expressão é sua. Você fala mesmo que pretendeu escrever um contra-mapa, e a expressão é ótima!

LV: A ideia que se tinha de Luanda não tem nada a ver com aquilo, por isso é que eu grafei com dois "us"; porque aquela é a cidade de Luuanda, era... As pessoas podem dizer, "Sim, sim, essas coisas, se calhar, passaram-se, eu vi”. Mas ninguém dava conta daquilo, nem os sítios, nem os personagens, nem as ações; nada daquilo ... Como se aquela realidade não fosse visível e, assim, aquilo não era a realidade, a realidade era outra, a Luanda dos colonos e dos colonizados mais próximos das ruas de alcatrão.

RC-JK: E como foi a recepção?

LV: A história da Vavó Xíxi e do seu neto foi uma história muito incômoda... As pessoas não gostaram muito daquela história. Porque os leitores, quem sabia ler e quem leu era gente que estava habituada a ler, e estava formada também numa outra imagem de si próprio, da sua classe, ou de seu grupo social... E aquilo vinha colocar uma outra perspectiva; uma perspectiva que eles não gostavam de admitir. E nas reuniões da Liga e da Anangola diziam, "bah, esses miúdos comunistas, vêm com essas leituras; não é nada disso". Digo contra-mapa neste sentido: aquela era a cidade que realmente era a cidade de Luanda e que existia por baixo de uma outra que era a que aparecia, já naquele tempo, 59, 60 .

RC-JK: Estaria aí a dimensão subversiva do livro?

$\mathbf{L V}$ : Já não me lembro muito bem em qual contexto é que eu disse isso, desse contra-mapa... Mas penso também nos espaços que lá estão definidos. Essa história se passou no Sambizanga, aquelas coisas que, ao tempo, eu próprio, enquanto fui crescendo, eram também referência para nós da Ingombota, Maianga... Nós tínhamos a percepção mais ou menos certa do que era. Mas dali para cima... Aos sábados, a gente ia todos divertir-se nos clubes, com alguns colegas que participavam conosco ou no desporto, ou no Liceu e noutras coisas. Era a minha própria descoberta daquela cidade e estava a devolver essa imagem, que não era a imagem de Luanda; por isso é que o livro foi ou era considerado subversivo. "Luanda não era nada disso".

RC-JK: A expressão contra-mapa é excelente, do ponto de vista espacial, do universo que você capta, e, também, 
no plano da linguagem. Você chega a dizer: "Eu queria que o português lesse e soubesse..."

LV: Sim; liam, diziam “isto é português", mas há qualquer coisa que escapa, que não é. É nesse sentido, a intenção foi essa. Que mesmo escrevendo na língua do colonizador, o colonizador lê e percebe que "É minha língua, mas não é minha língua". E isso era o argumento que nós tínhamos para essa diferença cultural, nos próprios termos culturais que eles nos impuseram. Dava-nos legitimidade para a autonomia ou a independência, ou o que fosse: havia uma diferença. E eles não podiam rasurar essa diferença. $\mathrm{E}$, sobretudo, nós estávamos legitimados a pedir um outro tipo de relação, porque já tínhamos uma diferença que era cultural, e não era uma questão só de haver o Movimento dos Intelectuais de Angola, não! O que eu depois percebi é que, fazendo aquilo, era mais do que uma intenção literária; havia um substrato cultural que justificava esta intenção. E se havia substrato cultural é porque foi formado durante muito tempo, muitas décadas, ou séculos, sei lá quanto foi. E que essa diferença nos dava razão. Penso que era assim que eu queria dizer. Pois era a cidade que, na verdade, não existia para ninguém, afinal, era aquela que existia e essa é que era a verdadeira cidade de Luanda para nós. Não era a outra.
RC-JK: Você identifica pontos de contato entre Luuanda e O livro dos rios...

$\mathbf{L V}$ : Sim, em termos de linguagem. Porque a temática é sempre a mesma.

RC-JK: E assim é possível, também, interpretar agora $\mathbf{O}$ livro dos rios e O livro dos guerrilheiros como um contra-mapa da Angola...

LV: Ah, isso é! Depois de $92 \mathrm{eu}$ percebi que os termos já não podem ser os mesmos, porque tudo se passa noutra época; a época histórica é outra, o contexto histórico-cultural também é outro. A independência é um facto radical, quer tenha dado certo, quer não tenha dado, quer seja uma independência só política... essas questões são questões menores, perante o facto. Angola foi colônia até aquele dia. A partir dali, é um país soberano, acabou. Que isso se misture com toda espécie de outras datas, não interessa. Portanto, o problema é essa perplexidade literária. Como é que agora, nessas novas condições históricas, histórico-sociais, históricoliterárias, nós vamos continuar? Os escritores vão continuar a ser aquilo que sempre foram? A voz crítica da intervenção cívica. Não é política, é cívica, que é uma tradição, que foram buscar às origens, aos textos, no século XIX. Pronto, está mais do que claro; 
mas, se quiser recuar até onde há coisas escritas, o poema do "Capitão de Cavalos", o Antônio Macedo, lá no século XVII, um mulato, se não me engano, ele é quem faz aquele poema a criticar o Triunvirato, os três que são um; já é um poema de intervenção sobre a realidade daquele tempo: "Como é que aqui três capitães é que são o governo, não há um capitão?...”. Pronto, é essa tradição cívica.

RC-JK: Você há anos vive fisicamente longe de Angola. E quais são as suas sensações diante da Luanda de hoje?

LV: Vou a Luanda, vejo, passeio, ando, oiço, e só oiço o que eu já sei... e por isso dizem... falam, converso, entro logo no tipo de linguagem, no comportamento, nos problemas, nada me é estranho. E, ao mesmo tempo, eu não sou capaz de passar daquilo. Entro no candongueiro e nada me é estranho, mas ao mesmo tempo é... O povo (claro, os jipes, os carros e não sei o quê; essa parte sempre houve e é outra coisa), agora, o povo de Luanda move-se com aquele sistema de transporte que se criou durante os primeiros anos da independência e que se mantém. Não há maneira de dar a volta àquilo e a Luanda de hoje é uma Luanda informal. A que nós vemos é a Luanda formal, estamos a ver uma Luanda, entre aspas, como se fosse a Luanda do colono. Agora a Luuanda onde é que está? Eu não quero acreditar no que eu vejo, no que eu oiço; porque isso é o que eu já via, já ouvia, não quero acreditar que seja só isso, que seja o que é significativo na realidade de hoje. A realidade de hoje é outra coisa.

RC-JK: Como essa realidade é representada na literatura contemporânea?

LV: E é isso que eu vou procurar na literatura atual, e na verdade encontro, mas é, assim, alguma porta lateral: é o erotismo, a ironia, é o gozo, é a formulação erudita, que são traços novos, e que estão lá, mas eu digo: “E Luuanda...?”. Que é isso o que se pede à literatura de um país que já é independente. Continua a ter o pendor que tem, que sempre teve, de intervenção, mas isso já pode ser feito com outro tipo de trabalho literário, porque o país é independente. Já há uma literatura nacional, que é muito antiga, é muito estudada... não quero ser injusto com outras Literaturas Africanas. Ainda que o corpus possa ser do mesmo valor etc., há uma diferença de tom na Literatura Angolana, que mostra que é uma literatura muito mais antiga, muito mais trabalhada, com muito mais aportes e muito mais enraizada numa cultura nacional, que não é só uma das culturas originárias, 
das culturas nativas; não, é outra coisa. Mas posso ser eu que estou aqui a divagar; que sempre dizem "ah, vocês têm a mania, os angolanos...”. É fácil descambar a autoestima em orgulho e o orgulho em arrogância, é fácil! Concedo, estou a ser arrogante; mas não é desmerecer o quer que seja... é apenas uma das literaturas de língua portuguesa...

RC-JK: E a Angola que há para além de Luanda?

LV: Acho que a realidade de hoje também não conheço... estive no Lubango, estive no Huambo, vi outras coisas, mas não conheço bem. Nunca nenhum de nós conheceu bem a realidade de Angola.

RC-JK: Como você vê a relação de seus últimos livros com o projeto literário angolano?

LV: O livro dos guerrilheiros e $\mathrm{O}$ livro dos rios, se fossem escritos na altura em que escrevi Luuanda, se calhar, tinha havido a apreciação de que era também um corte; eu tê-losia escrito de uma maneira que o corte era perceptível. Escrito já depois de uns anos, como está escrito agora, acho que não se nota que é um corte. Mas, eu sinto esse livro, esse trabalho a partir do $\mathbf{O}$ livro dos rios, sinto como um corte em relação ao anterior e acho que tem mais importância $\mathbf{O}$ livro dos rios, na Literatura Angolana, do que o Luuanda. Só que o que hoje tem importância na realidade não assinalei. São tantas coisas, e tão grandes, e passam-se tantas coisas... mais livro, menos livro... Eu, em certa altura, dizia que eu gostava de escrever agora um livro que fosse para o momento atual, que tivesse o impacto que teve o Luuanda, e aparentemente não escrevi. Não tem; já nenhum livro pode ter mais o impacto que tinha a literatura naquele tempo. Não é o Luuanda, ou O grande desafio, do Jacinto, ou a Sagrada esperança. A não ser (e ninguém lê o futuro), que as coisas evoluam de tal maneira que, de repente, um livro faz de novo mexer tudo; agora já não faz mexer nada. Nem os leitores, nem as livrarias. Mas eu estou tranquilo quanto ao o que escrevi.

RC-JK: Uma das marcas fortes de Luuanda não estaria efetivamente num pacto entre a literatura e o espaço de exclusão, por exemplo, que é um pacto radical?

LV: Não tem ambiguidades. Nós estamos daquele lado.

RC-JK: Você não acha que, depois, no final dos anos 70, começo dos anos 80 , há um pacto entre a literatura e o país novo. Há um desejo. Está tudo bem 
ou, aquilo que está mal começa a ser visto. Em $\mathrm{O}$ cão e os caluandas e em Quem me dera ser onda, dois livros muito bons, há uma desconfiança, que é tratada ali ...

$\mathbf{L V}$ : Com o humor de quem sabe ou pensa que "Isso vai passar, vai passar. Isso é ilusão de uma camada egoísta; amanhã já não é assim”. É um bocado lúdico, ambos os livros são lúdicos. As leituras que se fazem agora já podem ser vistas de outro modo, mas acho que eles escreveram deste ponto de vista.

RC-JK: Ali o pacto ainda aparece. O que nós, leitores, sentimos hoje, sobretudo os leitores mais velhos, é que há uma dificuldade de identificar esse pacto. Talvez esteja na base de uma certa ambiguidade, por exemplo, a opacidade de Luanda. Luanda tornou-se uma cidade opaca para esses habitantes?

$\mathbf{L V}$ : A cidade desenvolveu-se também em múltiplas direções e camadas. $\mathrm{O}$ caldo está muito mais engrossado, por estes anos todos. E o escritor já não tem, ou a capacidade, ou a oportunidade de participar de tudo; e já não tem, se calhar, a necessidade de ter a paciência para perceber aquilo em que não participa, ou não tem interesse em perceber.
RC-JK: Mesmo se saímos da esfera dos escritores, sente-se uma certa impaciência com os pobres. Nas ruas, muitas vezes, a resposta a um mutilado que pede ajuda é "Vá pedir ao Zé Eduardo". Vamos colocar nesses termos: há uma incomunicabilidade com a Luanda miserável, que incomoda. E há uma incompreensão com essa Luanda informal a que você se referiu. LV: Sim... E eu acho que é também um pouco de má consciência, que faz com que digam "Ah, isso não é comigo. Vai procurar outro". Porque sabe que é com ele. Porque esses, que hoje têm essa atitude, são os que, em 75 , receberam o país. E é, se calhar, é um sentimento de "Caramba, não fomos capazes, eu também! E agora? Não vou... mas não admito que esse problema... isso não é problema meu. O que eu fiz foi isto; fizemos um governo, saiu um país, saiu tudo, portanto não venha ter comigo". E eu penso o contrário; é que está aí um governo, está aí um país. E como eu participei a fazer esse país, esse governo, tudo quanto está hoje, então, é comigo mesmo. Não é com os outros que entraram. Podemos dizer: "Não foi nada disto que combinamos". Mas claro que não foi, e agora?

RC-JK: Diante desse quadro tão surpreendente, como a literatura pode responder? 
LV: O problema, em termos literários, é: não foi isto que combinamos; como é que eu vou mostrar que não foi nada disto que combinamos? Já num novo contexto, já com novos protagonistas, e, portanto, os perigos são outros. Não sei se são maiores, se são menores, se são mais legítimos, menos legítimos. Essa é a perplexidade dos escritores angolanos, hoje. Talvez seja também porque já não é possível falar de um escritor luandense; quer dizer, a cidade já não cabe num escritor.

Submetido em: 15 de junho de 2015. Aceito para publicação em: 09 de outubro de 2015. 
OUTRAS VOZES 
